\title{
MEMBANGKITKAN YANG HAMPIR MATI: KINERJA UPTD PASAR BINA USAHA DALAM MEMAJUKAN PASAR TRADISIONAL DI MEULABOH
}

\author{
Zakarya $^{1}$, Alimas Jonsa ${ }^{2}$, Vellayati Hajad ${ }^{3}$ \\ ${ }^{1}$ Jurusan IImu Administrasi Negara \\ Universitas Teuku Umar \\ Email: jackdalima@gmail.com \\ 2Jurusan Ilmu Administrasi Negara \\ Universitas Teuku Umar \\ Email: alimasjonsa@gmail.com \\ ${ }^{3} J u r u s a n$ Ilmu Administrasi Negara \\ Universitas Teuku Umar \\ Email:vellayati.hajad@utu.ac.id
}

\begin{abstract}
Abstrak
UPTD Pasar merupakan pelaksana teknis dari Dinas Perdagangan dalam mengelola Pasar Bina Usaha Meulaboh Kecamatan Johan Pahlawan Kabupaten Aceh Barat. Penelitian ini melihat kinerja melalui UPTD Pasar melalui produktivitas, kualitas layanan, resposivitas, responsibilitas, dan akuntabilitas. Meode yang digunakan adalah kualitatif deskriptif melalui wawancara dengan narasumber terkait seperti kepala UPTD Pasar Bina Usaha Meulaboh, pedagang yang berjualan di Pasar Bina Usaha, dan masyarakat sebagai pengguna atau konsumen di Pasar Bina Usaha Meulaboh. Hasil penelitian menunjukan bahwa UPTD Pasar sudah efektif dalam mengelola Pasar Bina Usaha Meulaboh karena telah mengedepankan aspek responsivitas, responsibilitas, dan akuntabilitas yang dapat dilihat melalui pencapaian dalam kinerja UPTD Pasar saat ini. Pelayanan yang baik menghasilkan kepuasan dari pengguna pasar. Namun demikian UPTD Pasar juga masih memiliki kekurangan dalam aspek produktivitas dan kualitas layanan. Hal tersebut dapat dilihat dari kekurangan pegawai dan fasilitas pendukung dalam mengelola Pasar Bina Usaha Meulaboh
\end{abstract}

Kata kunci: kinerja, UPTD Pasar, mengelola, pasar tradisional

\section{RAISING THAT ALMOST DEAD: \\ UPTD PASAR PERFORMANCE IN ADVANCING TRADITIONAL MARKETS IN MEULABOH}

\begin{abstract}
UPTD Pasar is a technical implementer of the Trade Office in managing the Bina Usaha Market in Johan Pahlawan District, West Aceh Regency. This study looks at performance through the UPTD Market through productivity, service quality, responsiveness, responsibility, and accountability. The method used is descriptive qualitative through interviews with related sources such as the head of the Bina Usaha Market Unit, traders who sell at Bina Usaha Market, and the community as users or consumers at theBina Usaha Market. The results show that the Market UPTD has been effective in managing the Bina Usaha Market Meulaboh because it has put forward the aspects of responsiveness, responsibility, and accountability that can be seen through achievements in the current performance of the UPTD Pasar. Good service results in satisfaction from market users. However, UPTD Pasar also still has shortcomings in terms of
\end{abstract}


productivity and service quality. This can be seen from the lack of employees and supporting facilities in managing the Bina Usaha Market in Meulaboh.

Keywords: performance, UPTD Market, managing, traditional market

\section{PENDAHULUAN}

Pasar adalah sebuah tempat di mana masyarakat melakukan kegiatan jual beli produk atau jasa yang telah diproduksi. Bahkan sebuah pasar terutama pasar tradisional dianggap sebagai fondasi penting ekonomi sebuah negara, termasuk di level provinsi dan kabupaten/kota dan merupakan cerminan tolak ukur dari ekonomi kerakyatan yang masih berjalan kuat sampai saat ini. Tetapi, dengan gencarnya ekspansi pasar modern yang dikelola dengan baik oleh pihak swasta yang jauh lebih profesional dalam pengelolaan manajemen maka semakin membuat pasar tradisional semakin tersaingi.

Kalau dibandingkan dengan pasar modern, maka keberadaan pasar tradisional pada dasarnya lebih menjanjikan dan memberikan ruang yang lebih besar bagi UMKM atau Usaha Mikro, Kecil, dan Menengah untuk dapat maju dan bersaing selain juga memiliki nilai plus yaitu nilai sosial budaya yang tidak di miliki oleh pasar atau tempat pembelanjaan moderen saat ini sebagai sebagai pasarnya masyarakat yang identik dengan tawar menawar dan juga mampu membuka banyak lapangan kerja yang lebih luas bagi masyarakat ekonomi ke bawah.
Peningkatan sarana dan prasarana yang menunjang keberadaan pasar tradisional dilakukan pemerintah untuk mendukung kegiatan di pasar tradisional dan bertujuan untuk memperkuat minat dan gairah jual dan beli masyarakat dan pedagang di pasar tradisional dan mampu mendongkrak perputaran uang dan perekonomian daerahnya. Maka dengan tujuan itu, sangat perlu untuk pasar tradisional di setiap daerah harus ditinjau kembali terutama kondisi fisik, kelayakan dan sumber daya lainnya yang mendukung kegiatan pasar untuk menggambarkan kelayakan menggunakan pasar dari segala aspek seperti aspek manajemen suplai barang dan aspek penunjang keamanan, kesehatan serta kenyamanan pelaku usaha di pasar dan lokasi dagang para penjual.

Pasar Bina Usaha ialah pasar daerah yang bertipe Pasar Tradisional/Pasar Rakyat yang dibangun oleh Pemerintah Daerah dan selanjutnya dikelola dan dikembangkan oleh UPTD Pasar. Pasar tradisional adalah tempat usaha yang terdiri atas toko-toko, kios, pasar berbentuk los dan tenda yang dimiliki atau dikelola oleh pedagang kecil, pedagang kaki lima, swadaya masyarakat dan koperasi dengan usaha kecil, modal kecil. 
Kegiatan perdagangan di pasar tradisional biasanya menjual berbagai kebutuhan sehari-hari seperti: (1) bahan makanan berupa ikan, daging, telur, sayur-sayuran, dan kue; (2) bahan pakaian; (3) perabot rumah tangga dan beragam kebutuhan sehari-hari lainnya dan berlangsung dengan sistem tawar menawar.

Pasar dan segala problematika di dalamnya telah banyak di teliti oleh peneliti sebelumnya. Diantaranya berbicara tentang aktivitas pedagang, pengelolaan dan lokasi berdagang. Salah satu yang menarik adalah penelitian yang mengatakan bahwa terdapat stigma buruk yang melekat pada pasar tradisional selama ini, membuat Kementerian Perindustrian perdagangan Koperasi dan UKM yang menaungi UPTD Pasar dan pengelola pasar menilai bahwa pengelolaan pasar tradisional di seluruh daerah Indonesia memberikan stigma di masyarakat (Nurhayati, 2016).

Penelitian ini dilakukan di Meulaboh Kabupaten Aceh Barat tepatnya di Pasar Bina Usaha, tepatnya komplek Pasar Bina Usaha Meulaboh yang di bangun oleh Pemerintah Daerah dan dikelola oleh UPTD Pasar untuk menata ruang wilayah pasar tradisional Meulaboh tersebut dan menunjang perekonomian masyarakat Aceh Barat di tengah berbagai keterbatasan lapangan kerja di sektor formal, maka berkecimpung dalam bisnis menjadi pilihan yang menarik karena dengan modal kecil seperti berjualan di pasar atau menjadi pedagang kaki lima (PKL).
Sehingga, dengan menjamurnya pedagang maka pemerintah daerah khususnya UPTD Pasar perlu memerhatikan pasar yang di jadikan tempat berjualan untuk menstabilkan perekonomian dan pendapatan daerah atas distribusi pengelolaan Pasar Bina Usaha.

\section{METODE}

Sebagai upaya untuk mengetahui kinerja UPTD Pasar Bina Usaha dalam mengelola eksistensi pasar tradisional, maka penelitian ini menggunakan metode penelitian kualitatif yang mampu menggambarkan kondisi pasar tradisional di tengah gempuran pasar modern. Selain itu, metode ini juga mampu digunakan untuk menyelidiki dan memahami sebuah peristiwa dan interaksi yang terjadi di pasar dengan mengumpulkan informasi-informasi penting yang selanjutnya diolah secara intergratif dan komprehensif sehingga mampu diperoleh pemahaman yang mendalam tentang tentang kinerja UPTD Pasar Binaa Usaha dan masalah yang dihadapinya. Tujuan akhir metode ini adalah masalah dapat terselesaikan sesuai perkembangan yang terjadi $d$ lokasi penelitian (Moleong, 2007).

Lokasi penelitian ini adalah di Pasar Bina Usaha Meulaboh Kabupaten Aceh Barat Provinsi Aceh yang juga merupakan blokasi langsung tempat para pedagang yang berjualan baik dalam ruko maupun pedagang kaki lima berjualan yang akan diteliti dan juga dapat melihat secara langsung 
bagaimana aktivitas yang ada dilapangan serta melihat realisasi kerja para pegawai Unit Pelaksana Teknis Dinas (UPTD) Pasar dilapangan. Narasumber dalam tulisan ini diperoleh dengan cara purposive sampling atau sudah terlebih dahulu diitentukan dan diutamakan orang yang memiliki power dan otoritas di lokasi penelitian sehingga dapat membantu berbagai akses informasi (Sugiyono, 2008). Mereka adalah Pegawai UPTD Pasar Bina Usaha Meulaboh (1 orang), Pedagang Kaki Lima (PKL) (5 orang), Pedagang Dalam Ruko (2 orang), dan masyarakat sebagai konsumen atau pembeli di Bina Usaha Meulaboh (3 orang). Data hasil wawancara yang telah dikumpulkan selanjutnya akan dianalisis dengan cara analisis kualitatif, yaitu melalui interpretasi data yang ditemukan untuk selanjutnya dilakukan pengambilan kesimpulan dan verifikasi dengan menggunakan interactive mode.

\section{HASIL DAN PEMBAHASAN}

\section{Profil UPTD Pasar Bina Usaha Meulaboh}

UPTD Pasar pada dasarnya adalah organisasi Pelaksana Teknis dari Dinas Perdagangan yang dibentuk oleh Pemerintah Kabupaten Aceh Barat untuk mengelola aset milik Pemerintah Daerah. Sedangkan dulunya, UPTD Pasar berada di bawah Dinas Perdagangan Kabupaten Aceh Barat UPTD Pasar dan pernah pula menjadi UPTD Pasar di bawah Dinas Perdagangan Kabupaten Aceh Barat yang sebelumnya di bawah instansi
DPKKD atau Dinas Pendapatan Pengelolaan Keuangan Dan Kekayaan Daerah Kabupaten Aceh Barat, Maka, pada akhir tahun 2018 UPTD Pasar baru beralih kewenangannya kepada Dinas Perdagangan Kabupaten Aceh Barat.

UPTD Pasar sebagai pelaksana teknis Dinas Perdagangan yang mengatur serta mengelola Pasar Bina Usaha Meulaboh yang ada di lapangan sesuai dengan Peraturan Bupati Aceh Barat Tentang Kedudukan, Susunan Organisasi, Tugas, Fungsi, dan Tata Kerja Unit Pelaksana Teknis Daerah Pasar Pada Dinas Perdagangan Kabupaten Aceh Barat. Dengan ada peraturan tersebut maka UPTD Pasar memiliki tanggungjawab penuh atas Pasar Bina Usaha Meulaboh dan beberapa aset daerah berupa beberapa ruko yang ada di Kabupaten Aceh Barat dan Kota Medan, hasil dari pengelolaan aset tersebut akan masuk ke (PAD) Pendapatan Asli Daerah Kabupaten Aceh Barat.

Awal pembangunan Pasar Bina Usaha Meulaboh di bangun pada tahun 1976 dengan satu komple Pasar Bina Usaha Meulaboh, lokasi tempat berdirinya UPTD Pasar berada pada Jalan. H Daud Dariyah, tepatnya terletak di Desa Ujong Kalak, Kecamatan Johan Pahlawan, Kabupaten Aceh Barat. Kantor UPTD Pasar berada dalam kompleks ruko pasar sudut kanan lantai dua Pasar Bina Usaha Meulaboh. Pasar Bina Usaha saat ini memiliki beberapa unit kompleks pasar yang berada di kompleks Pasar Bina Usaha serta beberapa fasilitas untuk menghasilkan 
PAD (pendapatan asli daerah) Kabupaten Aceh Barat dan menunjang kegiatan para berdagang untuk berjualan di pasar bina usaha. Berikut disajikan dalam tabel 1. Beberapa fasilitas yang ada Pasar Bina Usaha terdiri dari:

Tabel. 1 Fasilitas Pasar Bina Usaha

\begin{tabular}{clllc}
\hline No & \multicolumn{1}{c}{ Nama } & \multicolumn{1}{c}{ Ket } & \multicolumn{1}{c}{ Harga sewa/thn } & Jumlah unit \\
\hline 1 & $\begin{array}{l}\text { Komplek Ruko } \\
\text { Bina Usaha }\end{array}$ & Pasar terisi & Rp. 3.000.000 & 228 \\
\hline 2 & Komplek Pasar Ayam & 15 pedagang & Rp. 5000/Kandang & 1 \\
\hline 3 & Komplek Pasar Sayur & 24 pedagang & Rp. 1000/Meter & 1 \\
\hline 4 & Rumah Daging & $7 \times 12$ meter & Rp. 33.000.000/Thn & 1 \\
\hline 5 & Mushalla & $15 \times 15$ meter & - & 1 \\
\hline 6 & Toilet & $2 \times 2$ meter & Rp. 2000 & 6 \\
\hline 7 & Tempat Parkir & $12 \times 25$ meter & Rp. 1000/Motor & 2 \\
\hline & & & 240 \\
\hline
\end{tabular}

Sumber: Data Pasar Bina Usaha Meulaboh, 2019

Visi yang ditargetkan oleh UPT Pasar adalah "kami bangga apa bila PAD tercapai target," diantaranya pelaksanaan tugas sesuai dengan kewenangan dan ber acuan pada peraturan yang berlaku: (1) menjalankan hubungan kerja sama baik dengan masyarakat pasar; (2) melakukan pembinaan, penataan dan pengawasan terhadap perkembangan pasar; (3) memudahkan proses administrasi yang menjadi kebutuhan masyarakat pasar; (5 orang), sembari melakukan evaluasi, monitoring dan koordinasi terhadap hambatanhambatan di lapangan; (6) mencari peluang yang lebih baik demi meningkatkan PAD. (7) dalam melaksanakan tugas mengedepankan asas manfaat: manfaat untuk daerah, manfaat untuk pengelolaan dan manfaat untuk gampong.

\section{Tugas Dan Fungsi UPTD Pasar Bina Usaha}

Seperti kedinasan lainnya UPTD Pasar juga memiliki tugas dan fungsinya sendiri sebagai pelaksana teknis dari Dinas Perdagangan untuk mengatur seluru kegiatan di Pasar Bina Usaha Meulaboh. Sebagai mana tercantum pada pada Peraturan Bupati Aceh Barat Nomor 5 Tahun 2018 UPTD Pasar memiliki tugas dan tanggung jawab untuk mengelola Pasar Bina Usaha Meulaboh terdapat Tugas Dan Fungsi: (1) UPTD Pasar mempunyai fungsi untuk melaksanakan sebagian tugas teknis penunjang operasional dinas perdagangan, dalam hal pengelola pasar. (2) UPTD Pasar dalam melaksanakan tugas sebagaimana dimaksud pada ayat menyelenggarakan fungsi; Pengelola sarana dan prasarana pasar; (a) 
penyelenggaraan kegiatan pemungutan dan pendapatan; (b) penyelengaraan kegiatan ketertiban dan keamanan; (c) pelaksanaan kegiatan ketatausahaan; dan (d) pelaksanaan tugas-tugas kedinasan lainnya yang diberikan.

Dari tabel di atas dapat dapat di lihat jika pendapatan UPTD Pasar dari retrebusi para pedagang yang berjualan di Pasar Bina Usaha Meulaboh dari 2016,2017, dan 2018 sempat mengalami penurunan di tahun 2017, namun pada 2018 UPTD Pasar mulai meningkat dalam pendapatan retribusi dari para pedagang yang berjualan. Berbicara tentang struktur sebuah organisasi seperti UPTD Pasar maka pasti terdapat hierarki jabatan pada sebuah organisasi untuk mengatur keberlangsungan kinerja yang ada pada sebuah organisasi. Struktur organisasi pada UPTD Pasar Bina Usaha juga di atur pada Peraturan Bupati Aceh Barat Nomor 5 Tahun 2018 Pasal 3 Ayat 2 "UPTD Pasar di pimpin kepala UPTD dan bertanggung jawab langsung kepada kepala dinas melalui kepala bidang perdagangan." Struktur organisasi sangat di perlukan dalam memberikan wewenang dan pembagian tugas-tugas dalam melaksanakan tugas organisasi supaya setiap pegawai dapat mengontrol setiap tugas dan wewenang yang di berikan kepada kepada pegawai UPTD Pasar yang terdiri atas kepala
UPTD, kepala subbagian tata usaha; dan kelompok jabatan fungsional.

Pengatur dan orang yang menjalankan menjalankan tugas dan wewenang kedinasannya bisa berjalan dengan optimal sesuian dengan program kerja serta tugas dan funsinya sebagai pegawai kepemerintahan yang melayani public harus terdiri dari sumber daya manusia (SDM) karena merupakan unsur yang sangat penting di dalam institusi pemerintah. UPTD Pasar Bina Usaha saat ini terdiri dari 4 orang pegawai yang terdiri dari 3 orang Pegawai Negeri Sipil (PNS) dan 1 orang honorer yang berada dibawah wewenang UPTD Pasar. Selain pegawai yang berada di bawah susunan struktur organisasi UPTD Pasar terdapat pula sumber daya lain yang berkerja di UPTD Pasar untuk membantu UPTD Pasar dalam mengelola Pasar Bina Usaha, seperti yang di ketahui UPTD Pasar memiliki pekerja pembantu dari pihak ke 2 yang membantu mengelola keamanan dan kebersihan Pasar Bina Usaha Meulaboh. UPTD Pasar berkerja sama dengan pihak Desa Ujong Kalak, Dinas Kebersihan Kabupaten Aceh Barat serta TNI/POLRI untuk sistem keamanan dan Dinas Kebersihan Kabupaten Aceh Barat untuk sistem kebersihan UPTD Pasar. Berikut disajikan dalam tabel 2. Tentang Sumber Daya Manusia UPTD Pasar.

Tabel 2 Sumber Daya Manusia UPTD Pasar

\begin{tabular}{cccc}
\hline No & Status Kepegawaian & Keterangan & Jumlah \\
\hline 1 & Pegawai Negeri Sipil (PNS) & Pegawai UPTD & 3 \\
\hline 2 & Honorer & Pegawai UPTD & 1 \\
\hline
\end{tabular}




\begin{tabular}{cccc}
\hline 3 & Pejaga Malam & Keuchik Desa & 10 \\
\hline 4 & Petugas Kebersihan & Dinas Kebersihan & 7 \\
\hline 5 & PAM TNI dan PORLI & Koramil Dan Polres & 2 \\
\hline Total & & 23
\end{tabular}

Sumber: Data UPTD Pasar, 2019

UPTD Pasar yang mempuyai upaya dalam mengelola Pasar Bina Usaha Meulaboh supaya lebih baik lagi dalam berbagai hal untuk memberikan kualitas layanan kepada masyarakat pasar. Upaya UPTD Pasar dalam mengelola Pasar Bina Usaha dapat di ukur melalui indikator kinerja (Dwiyanto, 2006), maka untuk melihat apa saja yang telah di lakakan oleh UPTD Pasar untuk memperbaiki berbagai sektor yang mempengaruhi perdagangan. Sector yang dimaksud seperti produktivitas, kualitas layanan, responsivitas, responsibilitas dan akuntabilitas. Hingga saat ini, PUPTD Pasar Bina Usaha berupaya memberikan dampak positif dan mampu memenuhi target (PAD) Pendapatan Asli Daerah Kabupaten Aceh Barat.

\section{Kinerja UPTD Pasar Dalam Mengelola Pasar Bina Usaha Meulaboh}

Penelitian ini berfokus pada upaya UPTD Pasar dalam Mengelola Pasar Bina Usaha Meulaboh untuk memajukan dan menjalankan tugasnya sebagai pelaksana teknis dari Dinas Perdagangan untuk mengelola Pasar Bina Usaha. UPTD Pasar dalam mengelola retribusi atas pasar dan aset pemerintah daerah yang di tujukan atas wewenang UPTD Pasar untuk menghasilkan (PAD) Pendapatan Asli Daerah. dalam mengelola pasar pastinya banyak terjadi terjadi di lapangan serta kekurangan-kekurangan yang ada pada internal dan eksternal UPTD Pasar dan kompleks Pasar Bina Usaha, maka dengan itu dalam upaya UPTD Pasar dalam mengelola pasar Bina Usaha Meulaboh akan dinilai dari kinerja pegawai dan organisasi yang mengacu pada good governance yaitu dengan indikator berikut yaitu akuntabilitas, responsivitas, resposibilitas, produktivitas, dan kualitas layanan (Dwiyanto, 2006).

\section{Produktivitas dalam Mengelola Pasar Bina Usaha}

Produktivitas merupakan ukuran daya guna dalam melakukan atau melaksanakan pekerjaan seorang pegawai. oleh karenanya dalam berkerja pegawai harus bekerja dengan baik sesuai dengan tugas dan kewenangannya, di mana pegawai harus memiliki kualitas yang bagus dan mencerminkan bahwa dia adalah pelayan publik yang siap melayani, dalam melayani cara dan sikap dalam melayani menjadi tolak ukur bahwa pelayanan yang diberikan baik atau tidak. Bahkan dalam melayani untuk para pengguna pasar pegawai dan pengelola UPTD Pasar Pasar Bina Usaha 
Meulaboh, serta pegawai UPTD Pasar melakukan tugas yang menjadi tanggung jawab mereka dengan baik dan apabila dilihat dari tugas dan wewenang para pegawai UPTD Pasar sekarang ini menjadi lebih baik setiap harinya di dalam pelayanan.

\section{Kualitas Layanan Menggambarkan Kinerja Pegawai UPTD Pasar}

Kualitas layanan sangat perlu di dalam pelayanan publik karena representasi pelayanan dan performa pelayan yang baik akan memberikan dampak baik pada pandangan para pengguna jasa maka sebaliknya apa bila pelayanan di berikan buruk maka akan buruk lah pandangannya terhadap pemberi layanan. Kualitas layanan juga berkaitan erat dengan kualitas yang ditunjukkan oleh tampilan cara kerja, sumber daya manusia, produk, jasa, dan lingkungan yang dapat memberikan gambaran dan pandangan baik atau buruknya kualitas layanan yang di terima oleh pengguna layanan.

Untuk memberikan kualitas layanan yang bagus UPTD Pasar sebagai pengelola Pasar Bina Usaha Meulaboh berupaya penuh memberikan kualitas layanan bagi pengguna pasar meski UPTD Pasar banyak kekurangan terutama dalam hal fasilitas dan keberadaan sumber daya manusia yang cakap di bidang kerjanya. UPTD Pasar sebagai Pengelola Pasar Bina Usaha Meulaboh saat ini terus memberikan layanan kepada pengguna Pasar Bina Usaha Meulaboh, layanan yang diberikan sudah memadai dengan apa yang ada di Pasar Bina Usaha Meulaboh melalui fasilitas-fasilitas untuk pasar tradisioanal. Meskipun di Pasar Bina Usaha Meulaboh tersendiri banyak kekurangan dalam segi fasilitas namun saat ini Pasar Bina Usaha Meulaboh masih bisa mengatasi kekurangan tersebut sebagai pengelola Pasar Bina Usaha Meulaboh. Saat ini UPTD Pasar berupaya terus dengan pegawai dan petugas-petugas yang ada untuk meningkatkan kapasitas pelayan untuk pengguna pasar.

\section{Responsivitas UPTD dalam Penyusunan Agenda dan Menetapkan Prioritas Pelayanan}

Responsivitas sebagai bentuk kepekaan pemberi layanan untuk mengetahui apa yang perlu untuk kepentingan organisasi dan pengguna pasar dalam mengelola pasar supaya lebih baik lagi setiap hari. Untuk memberikan layanan yang optimal UPTD Pasar harus peka terhadap kebutuhan pasar saat ini dimana setiap saat terus berkembang. UPTD Pasar terus berupaya untuk memperbaiki kinerja dan fasilitas yang ada pada Pasar Bina Usaha Meulaboh, UPTD Pasar telah mengajukan penambahan pegawai agar mereka tidak kekurangan sumber daya manusia untuk bertugas dalam mengelola Pasar Bina Usaha Meulaboh dan saat ini UPTD Pasar dalam waktu dekat juga akan memperbaiki jalan los pasar dan membuat pintu portal masuk UPTD Pasar untuk mudah mengamankan pasar saat malam. 
2. Responsibilitas UPTD Pasar Sebagai

Pengelola Pasar Bina Usaha
Meulaboh

Sebagai pelayan publik UPTD

Pasar memiliki wewenang yang diberikan oleh instansi di atas untuk melaksanakan tugas dan kebijakan untuk mengelola Pasar Bina Usaha Meulaboh. Dalam menjalankan tugastugasnya untuk kepentingan organisasi nya terhadap instansi atasannya sebagai pemberi arahan untuk melaksanakan tugasnya. UPTD Pasar telah melaksanakan tugas dan kewajibannya sebagai pengelola Pasar Bina Usaha Meulaboh dengan melaksanakan instruksi yang menjadi tugas mereka dengan baik di dalam banyak kekurangan saat ini.

\section{Akuntabilitas Sebagai Tanggung Jawab UPTD Pasar Bina Usaha Meulaboh}

Tanggung jawab dimiliki oleh UPTD Pasar bukan hanya dalam mengelola pasar saja namun juga dalam pendapatan dari retribusi untuk meningkatkan Pendapatan Asli Daerah (PAD). Dalam hal ini UPTD Pasar sudah memaksimalkan tanggung jawab atas tugas yang di berikan untuk mengelola Pasar Bina Usaha, tidak ada kendala dalam penagihan retribusi baik penagihan kepada pengguna pasar baik penyetoran dana retribusi kepada Dinas Perdagangan.

Dari kelima indikator tersebut dapat dilihat bahwa pengelolaan UPTD Pasar dari segi manajemen sudah baik meski kekurangan para pegawai di kantor UPTD Pasar. Dari segi fasilitas sarana dan prasarana masih ada kendala dimana fasilitas yang ada di UPTD Pasar tidak terawat dan dijaga dengan baik, ini juga menjadi peran penting dari pedagang dan masyarakat sebagai pengguna Pasar Bina Usaha dalam menjaga serta merawat fasilitasfasilitas yang ada di Pasar Bina Usaha.

\section{SIMPULAN}

UPTD Pasar Bina Usaha sudah efektif dalam mengelola Pasar Bina Usaha Meulaboh karena telah mengedepankan aspek responsivitas, responsibilitas, dan akuntabilitas yang dapat dilihat melalui pencapaian dalam kinerja UPTD Pasar saat ini dengan baiknya respon UPTD Pasar atas setiap masukan pengguna pasar. Namun demikian UPTD Pasar juga masih memiliki kekurangan dalam aspek produktivitas dan kualitas layanan yang terlihat dari kekurangan pegawai (SDM) dan kurangnya tersedianya fasilitasfasilitas yang memadai.

Namun demikian, UPTD Pasar Bina Usaha sudah melakukan kinerja terbaik dalam mengelola kompleks pasar dan berbagai persoalan di dalamnya namun sebagai pasar tradisional masih banyak kekurangan sehingga membuat kurang efektifnya penggunaan Pasar Bina Usaha Meulaboh. Bangunan Pasar Bina Usaha Meulaboh sudah bagus namun masih ada kurang dalam hal fasilitas seperti parkir yang kurang memadai dan fasilitas toilet yang tidak bersih. Selain itu, terbatasnya jumlah pegawai UPTD 
Pasar mempengaruhi kualitas layanan UPTD Pasar terhadap pedagang dan masyarakat.

\section{DAFTAR PUSTAKA}

Dwiyanto, Agus. 2006. Reformasi Birokrasi Publik di Indonesia. Yogyakarta: Gadjah Mada University Press.

Fathoni, Abdurrahmat. 2011. Metedologi Penelitian dan Teknik Penyusunan Skripsi. Jakarta: Rineka Cipta.

Fattah, Nanang. 2004. Konsep Manajemen Berbasis Sekolah (MBS) dan Dewan Sekolah. Bandung: Pustaka

Herdiansyah, Haris. 2012. Metodologi Penelitian Kualitatif untuk IImuilmu Sosial. Jakarta: Salemba Humanika

Ismanidar, dkk. 2016. Persepsi Masyarakat Terhadap Pedagang Kaki Lima Di Kota Banda Aceh.Jurnal Ilmiah Mahasiswa Pendidikan Kewarganegaraan Unsyiah. Vol 1 (1) 147-157

Moleong, J Lexy. 2007. Metode Penelitian Kualitatif, Bandung: Remaja Rosda Karya

Nurhayati Cut. 2016. Strategi Dinas Koperasi Ukm Perindustrian Dan Perdagangan Dalam Penataan Pasar Tradisional Di Pasar Rakyat Kota Meulaboh Kabupaten Aceh Barat

Prawirosentono, Suyadi. 1999. Manajemen Sumber Daya Manusia: Kebijakan Kinerja Karyawan: Kiat Membangun Organisasi Kompetitif Menjelang Perdagangan Bebas Dunia. Yogyakarta: BPFE
Rahmanto. 2002. Penilaian Kinerja dan Imbalan: Suatu Alternatifkeluar Dari Krisis

Sugiono. 2008. Memahami Penelitian Kualitatif. Bandung: Alfabeta

Terry, R Geoger. 2006. Prinsip-Prinsip Manajemen. Jakarta: Bumi Aksara

Wibowo. 2007. Manajemen Kinerja. Jakarta: Pt. Raja Grafindo Parsada 